University of Montana

ScholarWorks at University of Montana

Winter 1992

\title{
The Politics of Language in Byron's The Island
}

James C. McKusick

University of Montana - Missoula, mckusickj@umkc.edu

Follow this and additional works at: https://scholarworks.umt.edu/eng_pubs

Part of the English Language and Literature Commons

Let us know how access to this document benefits you.

\section{Recommended Citation}

Copyright (C1992 The Johns Hopkins University Press. This article first appeared in $E L H$, Volume 59, Issue 4, Winter, 1992, pages 839-856.

This Article is brought to you for free and open access by the English at ScholarWorks at University of Montana. It has been accepted for inclusion in English Faculty Publications by an authorized administrator of ScholarWorks at University of Montana. For more information, please contact scholarworks@mso.umt.edu. 


\title{
THE POLITICS OF LANGUAGE IN BYRON'S THE ISLAND
}

\author{
BY JAMES C. MCKUSICK
}

Byron's late poem The Island: or, Christian and His Comrades (1823) has not proven especially congenial to modern sensibility; relatively little has been written about it, and most critics have tended to dismiss it as a regrettable episode in the Romantic idealization of the Noble Savage. Bernard Blackstone, in a 1962 study, expressed a fairly typical opinion: he sternly denounced the poem's "urge to regress to an infantile state of irresponsibility," and he elsewhere characterized it as "the escapist poem par excellence." 1 During the late 1960s, however, there was a brief spurt of interest in Byron's idyllic depiction of a South Sea island paradise of free love. Michael Cooke, in a 1969 study of Byron's poetry, defended the poem's final evasion of British naval authority, asserting that "the collapse of order, instead of meaning total chaos, may yield or lead to an island of happiness."2 Jerome McGann, in his classic study, Fiery Dust, offered perhaps the most persuasive defense of the poem's escapist tendencies, arguing that The Island is a deliberately unrealistic narrative, a "prophecy" in the manner of Shelley's Prometheus Unbound. In McGann's view, both of these poems "delineate a form of human possibility which yet requires the choice that determines accomplishment. . . . The vision of The Island is true because it may be true, always."3 McGann's study represents the high-water mark of enthusiasm for The Island; and in retrospect we can understand how its idyllic young lovers, Torquil and Neuha, must have evoked a sympathetic response on American campuses during the "summer of love."

Yet the poem is more nuanced in tone and more complex in its relation to the Romantic vogue for the primitive "state of nature" than many Byron scholars were willing to acknowledge during that exciting period of campus revolt. During the early 1970s a more sober and skeptical tone crept into critical discussions of The Island. In his still definitive study, Politics in English Romantic Poetry, Carl Woodring provided a carefully balanced view of the poem's relation to contemporary politics. Woodring pointed out that "The Island pays tribute repeatedly . . . to loyalty, discipline, authority, and 'whatever Duty 
bade." "Although "the idyll of Juan and Haidée returns [in this poem] as an endless dream, free from European politics, British justice, steel utensils, and Byronic irony," nevertheless the cave in which the fleeing lovers ultimately find refuge is merely a tropical version of Armida's bower, a stifling maternal retreat from the challenging world of masculine responsibility. ${ }^{4}$ In Woodring's analysis, The Island internalizes the contradiction between freedom and responsibility without attempting to resolve it; he therefore concludes that it is "a flawed poem of great interest," a view that is still apparently accepted by most Byron scholars, although most recent studies of Byron's poetry have either passed over this poem in silence, or dismissed it in brief footnotes. Indeed, remarkably little has been written about this poem since the flower-power era of the late 1960s.

Recently, however, The Island has begun to receive attention from critics sensitive to its intricate encoding of personal and political contexts. In particular, Angus Calder has convincingly demonstrated the historical specificity of Byron's references to Scotland throughout the poem. ${ }^{5}$ Calder argues that by invoking his own Scottish heritage, and by stressing the Orkney Island origin of his romantic hero, Byron adapts "the discourse of poetic tartanry" to a concrete political purpose: the legitimation of revolutionary activity in the Greek archipelago. ${ }^{6}$ In Byron's view, the islands of Scotland, Polynesia, and Greece are imaginatively identical, since their remote elemental setting provides a secure refuge from tyranny and a nurturing-ground for national heroes of liberation. Like Woodring, however, Calder acknowledges the poem's internal contradiction: "The poem in fact presents two opposite versions of morality and does not try to reconcile them."7 For Calder, as for most modern critics, the poem's ardent patriotism, almost jingoistic in its heroic presentation of Captain Bligh, remains an acute embarrassment, since it undercuts Byron's apparent commitment to democratic values and the revolutionary overthrow of tyranny. Indeed, the poem's apparent pandering to the worst tastes of its audienceits sentimental appropriation of the Noble Savage myth and its blind allegiance to the British flag-raises serious doubts about its value as an index to Byron's poetic development, let alone his politics. Was Byron merely writing a craven potboiler to raise money, as he seems to imply in a letter to Leigh Hunt?8

Closer scrutiny of Byron's account of his motives in writing The Island may help to resolve our understanding of its political orientation. In addressing Leigh Hunt, a radical democrat, Byron may have sought to minimize his own commitment to the dominant ideology of patri- 
otism; yet his contempt for the "reigning stupidity" is curiously interwoven with a statement of his desire for stylistic self-difference:

I have two things to avoid - the first that of running foul of my own "Corsair" and style - so as to produce repetition and monotonyand the other not to run counter to the reigning stupidity altogether-otherwise they will say that I am eulogizing Mutiny. ${ }^{9}$

The conflicting public demands indicated in this letter may help to account for the seemingly schizophrenic stylistics and politics of The Island. On the one hand, Byron seems to be saying that he must avoid conformity with the style of his own earlier verse-romances, especially The Corsair (that archetypal embodiment of the Byronic Hero); on the other hand, he must display at least nominal conformity with the conservative political ideology of his predominantly aristocratic and upper-middle-class readership. Paradoxically, however, the public demand for political conformity is matched by an unspoken but inexhaustible demand for titillation; while his readers' desire for stylistic novelty conceals a nostalgia for old and familiar heroes of the Corsair type, a type that Byron had effectively superseded with a new kind of hero in Don Juan. ${ }^{10}$ Political conformity, as Frederic Jameson has pointed out, demands not only repression, but the return of the repressed in displaced or disguised form. ${ }^{11}$ The Island, I will argue, enacts the return of the political repressed, both thematically, in its handling of historical narrative sources, and stylistically, in its articulation of an unfallen "language of nature" as an alternative to the stifling traditions of Miltonic rhetoric and high epic diction.

The mutiny on the Bounty was a deeply political, and politicized, event. The mutiny of 28 April 1789 came to be widely regarded as a British equivalent of the Fall of the Bastille, endowed with all the attendant hopes and anxieties of those who witnessed that dramatic event and its turbulent aftermath. Just as the people of Paris rose up against tyranny, so too the "people" (as the crew was commonly called) of the Bounty rose up against the arbitrary and erratic rule of Captain Bligh, who has gone down in history, somewhat unfairly, as a brutal tyrant who drove the sensitive, well-educated Fletcher Christian to mutiny. Bligh was the first eyewitness to return to England with a detailed account of the mutiny; and his undeniably heroic 3600-mile journey in an open boat certainly made him a sympathetic figure in the eyes of the English reading public. Bligh's version of events, recounted in his Narrative of the Mutiny, on Board His Majesty's Ship Bounty (1790), was widely disseminated; and it even formed the basis 
for a dramatic production, The Pirates! or, The Calamities of Captain Bligh, at the Royalty Theatre in April-May $1790 .{ }^{12}$ But the capture of several mutineers on the island of Tahiti and their return to face courtmartial in England provided an alternative source of information about the events leading up to the mutiny; and the wealthy and influential relatives of Fletcher Christian were eager to exonerate their kinsman by blackening the reputation of Bligh.

So the struggle was joined, with pamphlet and counter-pamphlet exchanged between Edward Christian, brother of the mutineer, and Captain Bligh, who stuck firmly to his story that the mutiny was the result of an evil conspiracy among the "people" to murder their captain and return to their "female connections" in Tahiti. ${ }^{13}$ Edward Christian replied that his brother was driven to a "sudden unpremeditated act of desperation and phrenzy" by Bligh's cruel and arrogant behavior. ${ }^{14}$ The political issues at stake in this public debate were strikingly similar to those contested by Edmund Burke and Thomas Paine in the context of the French Revolution: whether, and under what circumstances, the people have the right to rebel against the authority of their rulers. As the mutiny on the Bounty faded into the stuff of legend, Captain Bligh came to be seen less sympathetically as a quasi-allegorical embodiment of established authority, while Fletcher Christian was admired as a bold revolutionary hero seeking to overthrow tyranny and reconstitute society on an egalitarian basis. The exotic allure of the South Seas undoubtedly contributed to the massive popularity of the Bounty legend, since Rousseau's state of nature, if it existed anywhere, could most likely be found-or reinvented-in those remote tropical islands. ${ }^{15}$ This legend was an irresistible topic for the first-generation Romantic poets. Coleridge once planned to write a narrative poem on the "Adventures of Christian, the mutineer"; and the voyage described in The Rime of the Ancient Mariner bears a distinct resemblance to the voyage of the Bounty. ${ }^{16}$ A somewhat more oblique thematic engagement with the Bounty legend occurs in Wordsworth's drama, The Borderers, in which an old sailor's confession that he marooned his captain in mid-ocean awakens tragic remorse in a rebellious youth who has abandoned a fatherlike figure to die on a barren plain. ${ }^{17}$

Byron's thematic approach to the Bounty legend reflects his conflicting attitudes toward revolutionary politics. On the overt or "official" level, The Island adheres closely to the version of events recounted by Captain Bligh, especially in the first canto, which condemns the mutiny as an inscrutably evil conspiracy. This "official" attitude cannot be dismissed as merely pandering to the tastes of the British reading 
public, since Byron often expressed a similar distaste for the rabblerousing democrats of his own time, such as William Cobbett and "Orator" Hunt; and he had nothing but contempt for the Cato Street Conspirators, who had plotted in 1820 to assassinate several Cabinet ministers as the first stage in a popular uprising. Byron's response to this pathetically inept conspiracy - and a telling allusion to the French Revolution-occurs in a letter to his close friend John Cam Hobhouse:

What a set of desperate fools these Utican Conspirators seem to have been. . . . And if they had killed poor Harrowby - in whose house I have been five hundred times - at dinners and parties his wife is one of "the Exquisites" - and t'other fellows - what end would it have answered? - "They understand these things better in France" as Yorick says - but really if these sort of awkward butchers are to get the upper hand-I for one will declare off, I have always been . . . a well-wisher to and voter for reform in Parliament-but "such fellows as these will never go to the Gallows with any credit." 18

Byron's revulsion at the Cato Street Conspiracy does not reflect a fundamental disagreement with the conspirators' ultimate political end, but a disapproval of their means: he is disgusted by their awkward attempt at butchery, and he reveals a stubborn loyalty to his own social class in his horror at the attempted murder of a personal friend and fellow-member of Parliament. Like the Cato Street Conspirators, the Bounty mutineers were clumsy, brutal, unwashed, and finally unsuccessful in their attempt to murder their masters and return to the Tahitian paradise of free love (and free food). Captain Bligh emerges from the first canto of The Island as a true-blue naval hero, rising above all obstacles to return the loyal remnant of his crew safely home to England. Byron's pride in his family's naval heritage, as well as his instinctive allegiance to aristocratic social values, undoubtedly prompted him to portray the mutiny from Bligh's point of view. ${ }^{19}$

Yet the charismatic figure of Fletcher Christian exerted a conflicting tug on Byron's sensibility, not simply as a source of rhetorical fascination, but as an allegorical embodiment of revolutionary politics. Just as Byron enthusiastically supported revolutionary movements in Italy and Greece, so too he was tempted to sympathize with Christian in his titanic struggle against the implacable forces of established authority. After Captain Bligh disappears from the poem, Byron enacts a gradual reversal in his poetic stance such that by the end of canto 3 his narrative voice actively encourages the mutineers in their seemingly futile flight from vengeance: 


\section{Love}

Freights the frail bark and urges to the coveAnd now the refuge and the foe are nigh Yet, yet a moment! Fly, thou light Ark, fly!

Particularly revealing is the narrator's reference to the mutineers' canoe as an "Ark," suggesting that, like Noah's Ark, it may provide a temporary haven from divine vengeance, and perhaps also that it contains the seeds of an ideal future society, more virtuous because more loving. This particular canoe is paddled by Torquil, Christian's young protégé, and Neuha, his beloved island girl, and their final escape from authority is predicated on the sacrifice of Christian and his comrades. Thus Byron has it both ways: mutiny is punished, but the youngest mutineer survives and remains free to realize the revolutionary ideal of liberation through the power of love.

Byron's reversal of sympathy during the course of the poem is mediated by his shifting reliance on a variety of subtexts, some overtly acknowledged and some hidden. In an introductory note to The Island, Byron declares:

The foundations of the following Story will be found partly in the account of the Mutiny and Seizure of the Bounty in the South Seas (in 1789) and partly in "Mariner's Account of the Tonga Islands."21

The poem is indeed heavily dependent on these sources, especially the first canto, which is essentially a versified redaction of Bligh's narrative of the mutiny on the Bounty.$^{22}$ The second canto incorporates a native song and some anthropological details from William Mariner's account of his lengthy residence in the Tonga Islands, where, as a youth of fifteen years old, he was the sole survivor of a ship's crew that was massacred by the islanders. ${ }^{23}$ Mariner's account is by no means an idyllic portrayal of these islanders as harmless children of nature; he depicts them as prone to rage, murder, thievery, cannibalism, and sporadic internecine warfare. Byron was certainly not oblivious to this aspect of Tongan culture, although he chose to emphasize the more idyllic aspects of island life in contrast to the prevailing violence of the European adventurers. The climactic battle in canto 4 of The Island, when Christian and his two surviving comrades take refuge on a towering pinnacle and wreak terrible vengeance on their pursuers before finally falling to their deaths, has no factual basis in the Bounty narrative, and has been regarded by previous commentators as a purely fictive invention. However, this battle is clearly adapted from a similar 
episode in Mariner's narrative, which describes how "a band of young chiefs, the heads of a conspiracy, took refuge from the rage of their adversaries" on an impregnable cliff. ${ }^{24}$ Mariner goes on to describe how these island rebels, besieged in their clifftop fortress, destroyed many of their adversaries, but were finally vanquished by the forces of a cruel and treacherous king. Mariner concludes his tale by lamenting "the fate of those rebellious men, who, so long ago, departed from the scene of public tumult, by dying in an unsuccessful attempt to change the order of things." 25 Byron is likewise sympathetic in his depiction of the mutineers' final heroic struggle against overwhelming odds, although his evident compassion for Christian and his comrades is hardly consistent with the poem's initial depiction of Christian, from Bligh's perspective, as a heartless betrayer of friendship, humanity, and all civilized virtues. Byron relies on Mariner's narrative to effect a radical transformation of Christian's character, from the villain of canto 1 into the flawed yet charismatic hero of canto 4 .

Byron's depiction of Fletcher Christian is not limited to the facts he obtained from the published account of Captain Bligh, for whom Christian's treachery was ultimately inscrutable. But Byron's reliance on other historical sources is obscured by Ernest Hartley Coleridge's 1901 edition of The Island, which provides copious annotation derived from the latest scholarship of his own day, rather than a survey of the historical sources actually available to Byron. ${ }^{26} \mathrm{E}$. H. Coleridge unequivocally states that "Byron's acquaintance with the details of the mutiny of the Bounty was derived exclusively from Bligh's Narrative; ... he does not seem to have studied the minutes of the court-martial on Peter Heyward and the other prisoners." ${ }^{27}$ Yet a careful reading of the poem indicates that Byron must have consulted this latter publication, since it was the unique source for several crucial facts incorporated into The Island, especially regarding the character and activities of Fletcher Christian subsequent to the mutiny. In particular, the Appendix to the minutes of the court-martial, written by Edward Christian, describes how his brother

advised them to go to an island called Tobooy, which was laid down in the charts by Captain Cook, though no European ship had ever landed there. This lies about seven degrees south of Otaheite, and it was chosen because it was out of the track of European ships. ${ }^{28}$

Byron echoes this statement in a note to canto 4 of The Island, explaining that the poem is set in "Toobonai, the last island where any distinct account is left of Christian and his comrades" (4:122n). ${ }^{29}$ The 
minutes of the court-martial also describe how the British naval vessel Pandora was dispatched to seek out and capture the mutineers, and how she eventually discovered many of them on the island of Tahiti, blissfully cohabiting with their local sweethearts. ${ }^{30}$ Perhaps of greatest importance to the thematic development of The Island is the description, in the Appendix, of a remarkable change in Fletcher Christian's demeanor:

These [captured mutineers] say, that Christian was always sorrowful and dejected after the mutiny; and before he left them, had become such an altered man in his looks and appearance, as to render it improbable that he would not long survive this dreadful catastrophe. ... Though they say he kept up good discipline in the ship, yet he was generally below, leaning his head upon his hand, and when they came down for orders, he seldom raised his head to answer more than Yes, or No. ${ }^{31}$

This description - quite different from the brash, impudent mutineer portrayed by Bligh - is evidently the unacknowledged source for Byron's depiction of Christian, in canto 3 of The Island, as a silent, brooding figure, detached from his comrades and responding to them only in monosyllables.

In Edward Christian's Appendix, Byron could also have found information on George Stewart, the historical prototype for the character of Torquil in The Island, whom Bligh simply describes as "a young man of creditable parents, in the Orkneys." 32 The Appendix adds:

All declare that Stewart was an excellent officer, and a severe disciplinarian; severe to such a degree as to be disliked by the seamen, though much respected for his abilities. Mr. Stewart was in bed when the mutiny broke out, and afterwards was neither in arms, nor active on the side of the mutineers; yet it ought not to be concealed, that during the mutiny he was dancing and clapping his hands in the Otaheite manner, and saying, "It was the happiest day of his life." He was drowned in the wreck of the Pandora. This gentleman is spoken of by all in terms of great praise and respect. He is said to have been the best practical navigator on board, even superior in that character to Captain Bligh and Christian. ${ }^{33}$

Several of these traits recur in Byron's characterization of Torquil. He is described in The Island as a native of the Hebrides, "tempest-born in body and in mind," who "deemed the deep his home" (2:168-70). Byron emphasizes his devotion to the craft of navigation and his innate leadership abilities, suggesting that he would have become "a patriot hero or despotic chief" no matter what the circumstances of his birth 
(2:180-204). Byron assigns Torquil no explicit role in the mutiny, thus tacitly exempting him from its guilt while rewarding his enthusiasm for the sensual pleasures of the South Sea islands. Byron developed the Appendix's implication that Stewart was the most likely of the mutineers to "go native," as well as its statement that, subsequent to the mutiny, Stewart was chosen as Christian's "second in command." 34 The close personal relationship between Christian and Torquil assumes great thematic importance in The Island; Byron posits an intimate, perhaps homosexual bond between them. ${ }^{35}$ He also hints that Christian's despondency results from his remorse at having caused harm to his protégé:

[Christian] glanced on Torquil, who lay faintly by. "And is it thus?" he cried, "unhappy boy!

And thee, too, thee-my madness must destroy."

Christian's transformation from villain to gloomy Byronic hero, the presentation of Torquil as a natural leader, and the development of a close personal bond between these two men, all derive from the facts related in the minutes of the court-martial and Edward Christian's Appendix. This document is a significant and unacknowledged source of historical information in The Island.

Byron's decision not to acknowledge this source has distinct political overtones, since his poem seeks (on the "official" level) to vindicate Bligh; thus to accord equal historical status to Edward Christian's scurrilous pamphlet would undermine the sanctimonious tone of the narrator. The poem's official ideology required "Mutiny" to be brutally suppressed, despite the incongruity of this position with the poem's occasional advocacy of revolutionary politics and the downfall of tyrants. By according Bligh's Narrative authoritative status in the first canto, and then relying on Edward Christian's alternative version of events for the rest of the poem, Byron seriously questions Bligh's self-confident image as a British naval hero, offering instead an old-style Byronic Hero in the figure of Fletcher Christian. ${ }^{36}$ Christian defies British naval authority in tones heavily reminiscent of Milton's Satan, responding to Captain Bligh's final plea for mercy only by replying that "I am in Hell!" (1:164). ${ }^{37}$ Cut from the same cloth as Manfred, Cain, and the Corsair (and mythically identifiable with Satan, Prometheus, and Napoleon), Christian thrives in struggle against impossible odds. The naval authorities, alerted by Captain Bligh, enter eagerly into the avenging role of Milton's God, savagely attacking the mutineers in 
their mountain fastness until all are captured or destroyed. Although Byron's heroic depiction of Christian's last stand has no basis in fact (since most English readers knew that Christian had actually escaped to Pitcairn Island), it was generally considered acceptable on ideological grounds; thus the reviewer for The Literary Chronicle (21 June 1823) states:

A closer adherence to the fact would have rendered the poem more interesting, but his lordship seems to think that poetical justice required the punishment of the mutiny, and we are too much attached to discipline ourselves, to quarrel with his lordship on this point. ${ }^{38}$

In the opinion of this reviewer, "discipline," or political conformity, is more important than truth; and "poetical justice" requires the suppression or distortion of historical fact. Byron clearly did not underestimate the "reigning stupidity" of his intended audience.

The Miltonic aspect of Byron's rhetoric is most apparent in canto 3 of The Island, when the defeated mutineers have taken refuge beneath a jagged rock. Like the fallen angels in book 1 of Paradise Lost, the mutineers are silent and helpless, almost paralyzed by despair, yet still defiant:

But now at rest, a little remnant drew

Together, bleeding, thirsty, faint and few;

But still their weapons in their hands, and still

With something of the pride of former will,

As men not all unused to meditate,

And strive much more than wonder at their fate.

Byron stresses the muteness of the mutineers; their predicament has robbed them of the confident rhetoric of rebellion that fueled their initial confrontation with Captain Bligh:

Then, when their drought was quenched, looked sadly round,

As wondering how so many still were found

Alive and fetterless:-but silent all,

Each sought his fellow's eyes as if to call

On him for language, which his lips denied,

As though their voices with their cause had died.

Even Christian, like Satan lying vanquished in the abyss, is momentarily stunned into silence by the overwhelming force of his adversary: 
Stern, and aloof a little from the rest,

Stood Christian, with his arms across his chest.

Still as a statue, with his lips comprest

To stifle even the breath within his breast,

Fast by the rock, all menacing but mute,

He stood; and save a slight beat of his foot,

Which deepened now and then the sandy dint

Beneath his heel, his form seemed turned to flint.

(3:85-96; emphasis added)

Why does Christian fall "mute" at this moment of crisis? Perhaps mutiny is muted by the realization that it is nothing but a demonic double of the hegemonic power that it opposes; lacking a distinctive language of its own, it can only parody the rhetoric of established authority. Deprived of an articulate mode of discourse, the mutineers can only convey their feelings through gestures and facial expressions; and these more "primitive" modes of signification suggest an alternative to the sterile epic diction of the poem's overtly Miltonic episodes.

This linguistic alternative is more fully developed in the poem's idyllic interludes. Torquil, whose wild-eyed innocence (and sexual prowess) is somewhat reminiscent of the youthful Don Juan, discovers connubial bliss with his Polynesian Princess in the pastoral paradise of the Friendly Islands. Rather like Don Juan and Haidée, Torquil and Neuha initially possess no common language and can communicate only wordlessly, through tone and gesture and the "language of eyes." Neuha is described as "the infant of an infant world" (2:127), suggesting her newness, her innocent, unfallen nature, and the Edenic quality of her South Sea island home. She communicates her desire "with eyes that were a language and a spell" (2:131), eliciting an eager response in Torquil, "the blue-eyed northern child" (2:163). Both Torquil and Neuha are "children" in the sense that they have regressed to an early stage of psychological development that not only relieves them of adult responsibility, but enables them to reinvent language as an unmediated instrument of desire.

The reader's first impression of Neuha occurs at the beginning of canto 2 , where she sings a "song of Toobonai," an authentic artifact of South Sea island culture that was versified by Byron from a prose translation published in William Mariner's account of the Tonga Islands. The erotic themes and exotic diction of this song-including several untranslated Tongan words - are rendered into English verse that is strongly reminiscent of the allegedly primitive poetry of Ossian. Mariner's narrative invokes this Ossianic prototype by presenting this 
prose-poem as "a sample of their descriptive songs, which in language, like that of Ossian, are plaintive and pathetic." 39 In this way the South Sea island songs are assimilated to the Celtic origins of Scottish culture, a connection that also is made explicit in The Island when Byron compares these "rude rhymes" to the ancient ballads of the Norsemen (2:98). Torquil's Celtic heritage and his childhood in the remote northern islands of Scotland provide a natural link with the island culture of the South Seas; indeed, his peculiar name is an Anglicized version of the name of a minor Ossianic hero, "Torcul-Torno," who inhabited a stormy Scandinavian island. ${ }^{40}$ (The Ossianic poem "Cathloda" recounts how this noble Viking warrior was slain, and his beautiful daughter imprisoned in a cave, by the cruel king of Lochlin.) As a fitting Polynesian counterpart to Torquil's island origins and Ossianic associations, Byron adopted Neuha's name from William Mariner's description of "the islands of Neuha . . known to navigators by the names of Traitor's island, and Cocos island." 41 "Both children of the isles" (2:274), Torquil and Neuha are exempt from the decadence of mainland culture and free to invent their own language.

The subversive political implications of this linguistic alternative become apparent in the final canto of The Island, when Torquil and Neuha escape their pursuers by hiding in an undersea cave, far removed from the poem's metaphysical strife. When Neuha first dives toward the cave, her destination is not communicated to Torquil by articulate language, but by the very action of diving; to save himself he must follow the route shown by "a streak of light behind her heel, I Which struck and flashed like an amphibious steel" (4:109-10). This odd metaphor implicitly compares the sparkling trail of bubbles following Neuha's foot to the flash of sparks from a flint and steel, an image that is soon thereafter literalized when she lights a fire inside the cave. In her bold bid for freedom, Neuha acquires the attributes of the aggressive, masculine, Western steel; the more passive Torquil is threatened by loss of masculinity when Neuha borrows his knife to make fire (4:144). The cave itself is womblike, an enclosed female space laden with tropical fruits that seem emblematic both of fertility and of forbidden fruit, like the tempting apple served by Eve to Adam, "fondly overcome with Femal charm," or the pomegranate eaten by Persephone in Hades, which doomed her to live there eternally. ${ }^{42}$ The limitations of the idyllic mode are suggested at various other points in the poem: Neuha's eyes cast an ominously seductive "spell" over Torquil (2:132), and their withdrawal from the temporal world is described, paradoxically, as a kind of tyranny: 
What deemed they of the future or the past?

The present, like a tyrant, held them fast:

Their hour-glass was the sea-sand, and the tide,

Like her smooth billow, saw their moments glide

$(2: 352-55)$

The present moment becomes a "tyrant" because it usurps all memory of the past and all desire for the future; evidently the masculine fear of engulfment by the devouring female operates as a threat to Torquil's sense of independent identity and purpose. ${ }^{43}$ Byron seems to be suggesting that his recurrent idyllic fiction of a "language of nature"what he elsewhere jestingly terms "the most pamby portions" of the poem - must be relativized by juxtaposition with other linguistic elements in order to avoid stalling the narrative and cloying the reader. ${ }^{44}$

Both the idyllic "language of nature" and the high epic diction of Christian's titanic struggle are satirically undercut by the homely figure of Ben Bunting, who provides recurrent moments of comic relief with his blunt vernacular diction. One clear indication of Ben Bunting's subversive linguistic role is the fact that he was singled out for abuse by contemporary reviewers, who objected to his profanity, his cynicism, and his smoking habits. ${ }^{45}$ Even E. H. Coleridge, in his edition of this poem, regretted "that no one suggested [to Byron] the excision of sections xix-xxi from Canto 2" (5:615n.); these are the lines where the discordant odor of Ben Bunting's pipe wafts into the nostrils of the young lovers, interrupting their evening reverie and providing the narrator with a point of departure for a humorous digression on "Sublime tobacco" (2:448). The extreme heteroglossia of this moment, despite the outraged response of Byron's contemporary critics, is an essential stylistic feature serving to undercut the pretensions of the poem's two dominant linguistic modes, the epic and the idyllic. Just as in Don Juan, where the narrator's jocular asides frequently expose the youthful hero's unconscious hypocrisy, so here the intrusive presence of Ben Bunting, as an agent of heteroglossia, represents the return of the linguistic repressed in the guise of crude vernacular epithets. The most dramatic instance of Ben Bunting's role as a satirical debunker occurs at the climactic moment of Torquil's parting from Neuha, just as Torquil is promising eternal fidelity:

"But whatsoe'er betide, ah, Neuha! now

Unman me not; the hour will not allow

A tear; I am thine whatever intervenes!"

"Right," quoth Ben, "that will do for the marines."

$(2: 528-31)$

James C. McKusick 
Byron explains in a note to this passage that he alludes to the old saying, "That will do for the marines, but the sailors won't believe it" (2:531n.), thus suggesting that Torquil, however unconsciously, may be deluding Neuha with false promises. It is not surprising that this line attracted a great deal of admonishment from contemporary reviewers, since it radically undercuts the sentimental pretensions of the poem's idyllic mode. ${ }^{46}$ Ben Bunting offers a similar parodic deflation of Christian's Miltonic rhetoric in canto 3, when he gets into a swearing match with his mate, Jack Skyscrape, just as Christian is striking his most heroic pose (3:121-38).

Far from being a belated sentimental appropriation of the Noble Savage motif, The Island reveals the inadequacy of post-Enlightenment culture generally - and British naval discipline specifically - as a means of coming to terms with the exotic remoteness of the South Sea islands and the unmediated relation to nature that, since the voyages of Cook and Bougainville, their idyllic inhabitants had come to represent. The poem's unspoken dependence on these cultural stereotypes, as well as its explicit references to Bligh's narrative of the mutiny on the Bounty and Mariner's account of the Tonga Islands, indicates the normative role of the European observer (and the English language) in Byron's appropriation of the myth of the Noble Savage. Yet Byron's profound alienation from the prevailing values of "civilization," particularly his aversion to Britain's vindictive treatment of mutineers, deserters, homosexuals, and freethinkers, suggests that his sympathies lie more on the side of "Christian and His Comrades" than he is altogether willing to admit, even to himself. ${ }^{47}$ This underlying psychological complexity, working at cross-purposes with the poem's "official" ideology, produces a cross-grained linguistic texture that reveals a great deal about Byron's underlying motives and his compositional practice. Through his internalization of Miltonic rhetoric, Tongan lyric, and proletarian vernacular, Byron was engaged in a reexamination of the linguistic possibilities offered by the opening of English poetry to cultural diversity, as he admitted voices from outside the mainstream of British and European literature. Perhaps even more than Don Juan, a poem whose flirtations with the exotic are always tempered by the implicit condescension of its satirical perspective, The Island explores the possibility of a discourse unfettered by the repressive values of "official" British culture and accessible to the revolutionary free-play of natural language in a remote, idyllic setting.

University of Maryland, Baltimore County 


\section{NOTES}

${ }^{1}$ Bernard Blackstone, The Lost Travellers: A Romantic Theme with Variations (London: Longman, 1962), 212; Byron (London: Longman, 1970-1971), 3:43. See also Blackstone's essay, "Guilt and Retribution in Byron's Sea Poems" (1961), reprinted in Byron: A Collection of Critical Essays, ed. Paul West (Englewood Cliffs: PrenticeHall, 1963), 31-41; and Blackstone's comments on The Island in Byron: A Survey (London: Longman, 1975), 263-65.

${ }^{2}$ Michael G. Cooke, The Blind Man Traces the Circle: On the Patterns and Philosophy of Byron's Poetry (Princeton: Princeton Univ. Press, 1969), 212.

${ }^{3}$ Jerome J. McGann, Fiery Dust: Byron's Poetic Development (Chicago: Univ. of Chicago Press, 1968), 202.

${ }^{4}$ Carl R. Woodring, Politics in English Romantic Poetry (Cambridge: Harvard Univ. Press, 1970), 222-25. Woodring alludes to Armida, the seductress of Rinaldo and Tancred in Tasso's Gerusalemme Liberata (1580), who enticed her lovers into a secret, enchanted garden. Byron sometimes referred to Lady Oxford as "Armida"; see Leslie A. Marchand; Byron: A Portrait (New York: Knopf, 1970), 135-38.

${ }^{5}$ Angus Calder, "'The Island': Scotland, Greece and Romantic Savagery," in Byron and Scotland: Radical or Dandy?, ed. Angus Calder (Totowa, NJ: Barnes \& Noble, 1989), 132-50.

${ }^{6}$ Calder (note 5), 135.

${ }^{7}$ Calder, 135.

${ }^{8}$ In a letter of 25 July 1823, Byron writes: "I am merely trying to write a poem [The Island] a little above the usual run of periodical poesy - and I hope it will at least be that;-You think higher of readers than I do-but I will bet you a flask of Falernum that the most stilted parts of the political 'Age of Bronze'-and the most pamby portions of the $<$ South Sea $>$ Toobonai Islanders - will be the most agreeable to the enlightened Public; - though I shall sprinkle some uncommon place here and there nevertheless" (Byron's Letters and Journals, ed. Leslie Marchand [Cambridge: Harvard Univ. Press, 1973-1982], 10:90).

${ }^{9}$ Byron's Letters and Journals (note 8), 10:90. More extensive analysis of Byron's political outlook is provided by Woodring (note 4), 148-229; and Malcolm Kelsall, Byron's Politics (Sussex: Harvester Press, 1987). Both of these authors agree that Byron's radical politics were only uneasily reconciled with his assertion of aristocratic identity.

${ }^{10}$ The resemblance of Fletcher Christian to Byron's earlier heroes of the Corsair type is discussed by Robert Hume, "The Island and the Evolution of Byron's 'Tales,' " in Romantic and Victorian, ed. W. P. Elledge and R. L. Hoffman (Rutherford: Fairleigh Dickinson Univ. Press, 1971).

${ }^{11}$ This is the essential argument of Frederic Jameson in The Political Unconscious: Narrative as a Socially Symbolic Act (Ithaca: Cornell Univ. Press, 1981); see especially his remarks on the dialogical organization of class discourse (83-88).

${ }^{12}$ Cited by Richard Hough, Captain Bligh \& Mr. Christian: The Men and the Mutiny (London: Hutchinson, 1972), 216. Bligh subsequently published a greatly expanded version of his narrative, entitled A Voyage to the South Sea Undertaken by Command of His Majesty for the Purpose of Conveying the Bread-Fruit Tree to the West Indies in His Majesty's Ship the Bounty (London: G. Nichol, 1792). Byron's reliance on this and other historical sources is examined by Curt Alexander Lotze, Quellenstudie über Lord Byrons "The Island" (Leipzig: Dissertation, Univ. of Leipzig, 1902.)

${ }^{13}$ William A. Bligh, A Narrative of the Mutiny on Board His Majesty's Ship Bounty (London: G Nichol, 1790), 9.

${ }_{14}^{14}$ [Stephen Barney], Minutes of the Court-Martial held at Portsmouth, August 12, 1792, on Ten Persons Charged with Mutiny on Board His Majesty's Ship Bounty with an APPENDIX [by Edward Christian] containing a full account of the real Causes and Circumstances of that unhappy Transaction (London: J. Deighton, 1794), 79. This pamphlet, together with Bligh's Narrative (note 13), was reprinted in facsimile (Melbourne: Georgian House for the Australiana Society, 1952). 
${ }^{15}$ Bernard Smith argues that the Bounty mutineers "chose to accomplish in real life an ideal that lay close to the romantic ideal of life - the desire to live in intimate and continuous contact with nature" (European Vision and the South Pacific, 2nd edition [New Haven: Yale Univ. Press, 1985], 327).

${ }^{16}$ Coleridge lists the "Adventures of Christian" as number 22 in a list of "My Works," The Notebooks of Samuel Taylor Coleridge, ed. Kathleen Coburn, 3 vols. (Princeton: Princeton Univ. Press, 1957), 1:174. Cuthbert S. Wilkinson, The Wake of the Bounty (London: Cassell \& Co., 1953), advances the claim that The Rime of the Ancient Mariner retraces the voyage of the Bounty.

${ }^{17}$ William Wordsworth, The Borderers, act 4, scene 2. At the time of writing this play (October 1796), Wordsworth was also engaged in an attempt to defend Fletcher Christian's reputation; on 23 October he wrote a letter to the editor of the Weekly Entertainer to denounce a publication supposedly authored by Christian. Wordsworth had been a schoolmate of Fletcher Christian at Hawkshead Free Grammar School, and he later became a close friend of Edward Christian. This topic is more fully developed by Geoff Sanborn in "The Madness of Mutiny: Wordsworth, the Bounty and The Borderers," The Wordsworth Circle 23 (1992): 35-42.

${ }^{18}$ Byron's Letters and Journals (note 8), 7:62-63.

${ }^{19}$ Byron's grandfather, Admiral John Byron (nicknamed "Foulweather Jack"), was the author of A Narrative . . of the Loss of the Wager Man of War (London: S. Baker, 1768); this harrowing tale of mutiny, starvation, and murderous brutality contributed to the shipwreck episode of Don Juan (canto 2). Admiral Byron's later successful voyage around the world is published in John Hawkesworth, An Account of the Voyages Undertaken by the Order of His Present Majesty for Making Discoveries in the Southern Hemisphere (London: W. Strahan \& T. Cadell, 1773), volume 1.

${ }^{20}$ All references to The Island in the text of this essay refer (by canto and line number) to the first edition (London: John Hunt, 1823). (This poem will soon be published in Byron's Complete Poetical Works ed. Jerome J. McGann [Oxford: Clarendon Press, 1980- ].

${ }^{21}$ The Island (note 20), page [6]. "Extract from the Voyage by Captain Bligh" is printed as an appendix to the first edition of The Island, 81-94. Lotze (note 12) conclusively demonstrates that this "Extract" is derived from the expanded 1792 edition of Bligh's Voyage (note 12), and not the 1790 Narrative (note 13), which is erroneously cited as Byron's source in The Works of Lord Byron, ed. Ernest Hartley Coleridge (London: John Murray, 1898-1904), 5:581.

${ }^{22}$ The most balanced and reliable account of the mutiny on the Bounty is provided by Gavin Kennedy, Bligh (London: Duckworth, 1978). Fletcher Christian and his comrades never fought such a fierce battle as described in The Island; rather, Christian escaped to Pitcairn with eight fellow mutineers, while the others surrendered to the British naval vessel Pandora when it arrived at Tahiti in 1791. The Pitcairn Island settlement was discovered by the American vessel Topaz in 1807, and visited by British naval vessels in 1813; these discoveries were reported in the Quarterly Review of February 1810 and July 1815 , but Byron apparently never heard of them. The American discovery of Pitcairn Island served as the historical basis for Mary Russell Mitford's poem, Christiana, the Maid of the South Seas (London: Printed by A. J. Valpy for F. C. and J. Rivington, 1811).

${ }^{23}$ William Mariner, An Account of the Natives of the Tonga Islands in the South Pacific Ocean. With an Original Grammar and Vocabulary of Their Language. Compiled and Arranged from the Extensive Communications of Mr. William Mariner, Several Years Resident in Those Islands. By John Martin, M.D., 2 vols. (London: Printed for the Author, and sold by John Murray, 1817).

${ }^{24}$ Mariner (note 23), 1:303.

${ }^{25}$ Mariner, 1:304.

${ }^{26}$ Carl Woodring (note 4) makes a similar observation regarding E. H. Coleridge's editing of Byron's historical tragedies (181). 
${ }^{27}$ Works of Lord Byron (note 21), 5:582. Coleridge refers to Minutes of the CourtMartial (note 14). These Minutes were transcribed from notes taken by Stephen Barney, attorney for the defense; the Appendix was written by Edward Christian, brother of the mutineer. Although this document is now quite rare, it does not seem intrinsically unlikely that Byron consulted it, since any library or personal collection that contained Bligh's Voyage might also contain Edward Christian's response, and Byron is known to have been an avid reader of voyages and travels from early youth (Marchand [note $4], 14)$.

${ }^{28}$ Minutes (note 14), 72.

${ }^{29}$ Byron apparently altered the name Tobooy (also spelled Tubuai or Toobouai in contemporary accounts) to Toobonai for reasons of euphony and versification.

${ }^{30}$ Minutes (note 14), 55-57, 75.

${ }^{31}$ Minutes, 74 and $\mathrm{n}$.

${ }^{32}$ Bligh (note 13), 8.

${ }^{33}$ Minutes, 72.

${ }^{34}$ Minutes, 72.

${ }^{35}$ Byron's oblique suggestion of a homosexual bond between Christian and Torquil is not supported by any historical evidence, although it has been suggested that Bligh and Christian were homosexual lovers before their arrival in Tahiti (see Hough [note 12], 296-305). Perhaps Byron had heard some rumor of the alleged intimacy between these two men, since he describes Christian as "the bold and froward boy, / His Chief had cherished only to destroy" (1:151). The topic of homosexual innuendo in Byron's poetry is more generally discussed by Louis Crompton in his controversial study, Byron and Greek Love: Homophobia in 19th-Century England (Berkeley: Univ. of California Press, 1985).

${ }^{36}$ My account of Byron's portrayal of Christian is indebted to Peter Thorslev, The Byronic Hero: Types and Prototypes (Minneapolis: Univ. of Minnesota Press, 1962), especially the chapter entitled "Satan and Prometheus" (108-24).

${ }^{37}$ This remarkable phrase also occurs in Bligh's Narrative (note 13), 8, although Byron situates it in a more overtly Miltonic context.

${ }^{38}$ The Literary Chronicle (21 June 1823): 387; reprinted in The Romantics Reviewed: Contemporary Reviews of British Romantic Writers, ed. Donald H. Reiman (New York: Garland, 1972), part B, 3:1339.

${ }^{39}$ Mariner (note 23), 1:305.

${ }^{40}$ Torcul-Torno appears briefly in "Cathloda: A Poem," in James Macpherson, Temora, an Ancient Epic Poem, in Eight Books: Together with several other Poems, composed by OSSIAN, the son of FINGAL (London: T. Becket \& P. A. De Hondt, 1763), Duan First, 185-87. Macpherson states that Torcul-Torno was "king of Crathlun, a district in Sweden" (185n). According to Archibald Clerk (a Victorian editor of the Ossian poems), "Torcul-now written as Torquil in English-is still common in the Hebrides as a man's name. The Macleods of Raasay were known as Siol Thorcuill, 'the race of Torquil.' Torno is a contraction of Uthorno, . . . probably meaning 'isle of storms or sounds'-an island of Lochlin [Scandinavia]." The Poems of Ossian in the Original Gaelic (Edinburgh: Blackwood, 1870), 77. "Torquil" is also the name of a minor character in Sir Walter Scott's The Lord of the Isles (Edinburgh: A. Constable, 1815); cited by Lotze (note 12), 35.

${ }^{41}$ Mariner (note 23), 2:331. Because of its thematic link with "Traitor's island," this seems a more plausible source for the name "Neuha" than the one proposed by the editor of The Works of Lord Byron (note 20), 5:609n, who derives her name from "Toobo Neuha," a Tongan chief mentioned by Mariner, 1:141.

${ }^{42}$ John Milton, Paradise Lost, second edition (London: S. Simmons, 1674), 9.999. Bernard Blackstone discusses the Miltonic implications of Neuha's tropical fruits in "Guilt and Retribution in Byron's Sea Poems" (note 1), 35.

${ }^{43}$ Peter Manning further discusses Byron's "uneasy attitude to women . . . springing from fear of maternal dominance" (Byron and His Fictions [Detroit: Wayne State Univ. 
Press, 1978], 188). I am particularly indebted to Manning's insightful discussion of the problem of muteness in the Haidée episode: "Don Juan and Byron's Imperceptiveness to the English Word," Reading Romantics: Texts and Contexts (New York: Oxford Univ. Press, 1990), 115-44.

${ }^{44}$ Byron's Letters and Journals (note 8), 10:90.

${ }^{45}$ The intrusive presence of Ben Bunting is severely criticized by the Monthly Review (July 1823): 319 and the New European Magazine (July 1823): 50-51. These reviews are reprinted in The Romantics Reviewed (note 38), part B, 4:1828 and 4:1869.

${ }^{46}$ Both of the reviews cited in note 45 single out this line for criticism; the Monthly Review calls it "prosaic," while the New European Magazine describes it as an instance of "doggrel sic, and incongruity, and bathos, and carelessness."

${ }^{47}$ Byron's profoundly ambivalent attitude toward the dominant moral values of British society is examined by Crompton (note 35); see also Jerome Christensen, "Setting Byron Straight: Class, Sexuality, and the Poet," in Literature and the Body: Essays on Populations and Persons, ed. Elaine Scarry (Baltimore: Johns Hopkins Univ. Press, 1988), 125-59. 